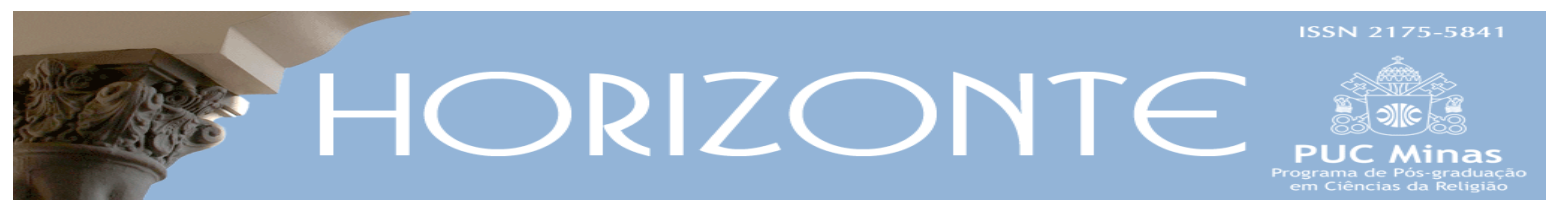

Dossiê: Fundamentalismos e Democracia - Artigo Original (c) (1)

\title{
A tradução fundamentalista: equivalências hermenêuticas entre teologias exclusivistas e modelos democráticos elitistas
}

\author{
The fundamentalist translation: \\ hermeneutic equivalences between exclusivist theologies \\ and elitist democratic models
}

\author{
Jefferson Zeferino* \\ Rodrigo de Andrade ${ }^{* *}$
}

\begin{abstract}
Resumo
O declínio democrático em vários países latino-americanos tem acompanhado o crescimento da força de setores religiosos. Este texto objetiva interpretar a presença pública das igrejas cristãs e de seus representantes políticos com base na tradução como processo hermenêutico que observa o modo das relações entre religião e espaço público. Por meio de uma análise bibliográfica, identifica-se na aplicação da hermenêutica ricoeuriana no campo de estudos da religião a possibilidade de interpretação das traduções concretas intersubjetivas e intercontextuais presentes no espaço público em duas frentes: numa dinâmica intralinguística, a saber, a relação entre grupos cristãos que possuem convergências suficientes para uma ação programática em pautas morais e econômicas; e numa dimensão interlinguística que pode ser observada na relação entre grupos religiosos e modelos democráticos elitistas cujo constante estado de crise não deixa de ser benéfico para determinados setores. A metáfora das religiões como idiomas, também permite a identificação de incompatibilidades hermenêuticas entre distintos discursos teológicos no espaço público mesmo quando oriundos da mesma tradição. Percebe-se, portanto, que a tradução como processo hermenêutico de análise de discursos teológicos pode se consolidar como mais uma ferramenta no campo de estudos das relações entre religião e espaço público.
\end{abstract}

Palavras-chave: Teologia pública. Teologia política. Teologias exclusivistas. Democracia representativa. Tradução.

\begin{abstract}
Democratic decline in various Latin American countries has been accompanied by religious sectors growth. This article aims at interpreting the public presence of Christian churches and their political representatives based on translation as hermeneutical process in which the relationship between religion and public space is observed. Through bibliographical analysis, the text identifies in Ricoeurian translation based hermeneutic applied to religious studies the possibility of interpreting concrete intersubjective and intercontextual translation which are already present in the public space, mainly in two ways: in an intralinguistic dynamics, i.e., the relationship between Christian groups that sufficiently converge onto programmatic actions regarding economic and moral agenda; and in an interlinguistic dimension in the relationship between religious groups and elitist democratic models which constant crisis situation is perhaps beneficial to some sectors. The metaphor of religions as languages also allows the identification of hermeneutic incompatibilities between distinguished theological discourses in the public space, even when they originate from the same tradition. Therefore, translation as hermeneutic process applied to the analysis of religious discourse may become another tool to the field of studies on religion and public space.
\end{abstract}

Keywords: Public theology. Political theology. Exclusivist theologies. Representative democracy. Translation.

\footnotetext{
Artigo submetido em 31 de julho de 2020 e aprovado em 26 de dezembro de 2020.

* Doutor em Teologia pela PUCPR. Bolsista PNPD/CAPES no Programa de Pós-Graduação em Teologia da PUCPR. País de origem: Brasil. E-mail: jefferson.zeferino@hotmail.com

** Doutor em Teologia pela PUCPR. Coordenador do Observatório de Evangelização da PUCPR. País de origem: Brasil. E-mail: rodrigo.andrade1@pucpr.br
} 


\section{Introdução}

Há vinte anos os estudos em teologia pública estão presentes no Brasil, tendo ganhado maior destaque na última década. Ao atingir sua maioridade, já é possível notar alguns movimentos bastante característicos nessas produções. Com efeito, por meio de um mapeamento dessas publicações foi possível detectar duas principais constantes: a preocupação por uma linguagem pública da teologia no âmbito acadêmico e na sociedade; e a abordagem das relações entre teologia/religião e espaço público/sociedade/política (ZEFERINO, 2018; 2020). Esta análise do campo brasileiro reverbera a compreensão sul-africana como elaborada por Jaco S. Dreyer (2011, p. 6), segundo a qual a teologia pública possui uma dupla missão: a análise das variadas práticas cristãs no espaço público, bem como a articulação de um testemunho público da fé cristã acessível a seus interlocutores. Assim, a teologia pública se moveria entre um polo analítico e outro propositivo. Este equilíbrio nos parece pertinente, uma vez que, na esteira da tradição judaico-cristã, compõe a tarefa profética de análise crítica da realidade apontando onde dói e denunciando o pecado do rei e do povo, bem como anunciando uma promessa de vida, proclamação da justiça em meio à injustiça.

Como veremos adiante, Dreyer enfatiza o imperativo da tradução, além de entender que a análise das traduções que já acontecem parece ser um ponto de partida concreto para a teologia pública. Assim, nos valemos da hermenêutica da tradução ricoeuriana aplicada aos estudos da religião (teologia pública e teologia das religiões) por Dreyer e Taylor para colocar em movimento aquilo que compreendemos como uma teologia pública em seus momentos crítico-analítico e crítico-propositivo.

Dentre as traduções teológicas presentes no espaço público, gostaríamos de destacar aquela que acontece entre modelos democráticos elitistas e os discursos 
teológicos exclusivistas ${ }^{1}$. A simbiose entre eles é possibilitada por meio de pontos de contato, equivalências e identificações. O que se diz de um Deus soberano e imperial de um lado, reverbera positivamente do outro. Não apenas em virtude dos agentes bilíngues ${ }^{2}$ (cristãos evangélicos e católicos conservadores na política, agentes políticos conservadores em igrejas cristãs evangélicas e católicas)³, mas de valores comuns traduzíveis a contento de um lado ao outro. Percebe-se aí a disposição de se abrir mão de uma tradução perfeita (que implicaria, numa perspectiva exclusivista, na transformação do outro no mesmo), permitindo uma comunhão de conveniência e conivência entre evangélicos e católicos de dialetos distintos dentro da mesma família linguística no contexto de um espaço público democrático em processo de transformação à sua imagem e semelhança.

O artigo está dividido em duas partes, seguida das considerações finais: a primeira desenvolve a noção de tradução como meio de análise dos discursos teológicos no espaço público, o segundo trata de pensar as relações de tradução entre modelos democráticos elitistas e modelos teológicos exclusivistas.

\section{A hermenêutica da tradução aplicada aos estudos da religião}

A tradução é um tema da filosofia de Paul Ricoeur (1913-2005) que, apesar de ser trabalhada em outros momentos, somente aparece de modo mais sistematizado tardiamente. A obra Sobre a tradução (RICOEUR, 2011), por exemplo, reúne textos apresentados em conferências nos últimos anos de vida do autor (1997, 1999 e 2004). O que nos interessa no presente momento é como esse recorte ricoeuriano é recebido no âmbito dos estudos da religião, mais

\footnotetext{
${ }^{1}$ À tentativa de imposição pública de agendas religiosas, Barros (2019, p. 317) utiliza a terminologia "posicionamento teológico-político exclusivista". Com base nesta afirmação, nos parece pertinente agregar à discussão do que se está entendendo aqui como fundamentalismo, justamente essa perspectiva teológica exclusivista. Nesse sentido, esta forma de construção de pensamento é avessa à pluralidade e tende a ler a realidade com base em normas tidas como reveladas e que, justamente por isso, crê-se que elas podem subjugar ou eliminar outras narrativas.

${ }^{2}$ A partir da noção das religiões e denominações religiosas como idiomas, pensa-se em agentes bilíngues. O conceito também é utilizado por Bedford-Strohm (2014) em sua explicitação do que compreende ser a capacidade de comunicar uma determinada mensagem numa dupla linguagem, a secular e a bíblico-teológica.

${ }^{3}$ Acerca da relação entre neoconservadorismo político e evangélico inclusive intercultural, entre Brasil e Estados Unidos, ver a recente tese de Lacerda (2018) intitulada Neoconservadorismo de periferia: articulação familista, punitiva e neoliberal na Câmara dos Deputados.
} 
especificamente no contexto do diálogo inter-religioso e teologia das religiões com James Taylor, e no contexto da teologia pública com Jaco S. Dreyer.

Aproveitando a senda aberta por Ricoeur, Taylor aplica a hermenêutica da tradução ao âmbito do diálogo inter-religioso. Destaca-se, assim, a relação entre os elementos que compõem cada religião como se cada uma fosse um idioma (textos sagrados, símbolos, práticas, tradições). A tradução inter-religiosa informa que cada religião possui algo a oferecer que a outra não tenha e, com isso, cada religião, abrindo-se à outra, deve superar a tendência exclusivista de autossuficiência, reconhecendo seus limites. Trata-se de entender que sua própria religião não é capaz de reduzir a outra a si mesma, ela é uma religião entre as outras, assim como o humano é um estranho entre outros e uma língua é uma entre outras. Somente com a perda da ilusão de uma religião perfeita é que se torna possível uma expansão de sentido mediada pelo encontro com a outra. A tradução inter-religiosa não deve operar uma terceira fala tolerável, mas que cada religião deve se colocar honestamente diante da outra, permitindo que sua narrativa seja por ela interpelada (TAYLOR, 2011, p. 18-20).

A tradução inter-religiosa, como qualquer abertura à alteridade, é um risco e uma aposta. Não se pode garantir que se tenham mais ganhos que perdas, e os efeitos devem ser analisados nas experiências concretas nas vidas de indivíduos e comunidades particulares que acolhem este desafio. De qualquer modo, na superação da aposta exclusivista, abre-se espaço também para uma perspectiva mais espaçosa e surpreendente daquilo que, em várias tradições, denominou-se como Deus. Quando uma religião se abre à tradução de seu Deus e traduz o Deus do outro, torna-se possível a substituição de uma imagem de Deus por outra mais alargada. Não em sentido imperialista, de soberania e onipotência, mas em uma compreensão de Deus, enquanto o estranho religioso por excelência, menos presa a categorias linguísticas normativas pré-definidas. Um Deus que não pode ser reduzido a qualquer tradição religiosa (TAYLOR, 2011, p. 20-21). 
Jaco S. Dreyer (2011, p. 2), teólogo sul-africano, ao seguir a metáfora entre religião e idioma proposta por Ricoeur, evidencia a necessidade de uma tradução intralinguística que, porém, não é suficiente no espaço público, sendo necessária uma tradução interlinguística. Em ambos os casos se faz necessária uma hermenêutica intercontextual, no primeiro, porque se lidam com tradições e textos sagrados de contextos diferentes daquele do leitor, no segundo, porque além da diversidade de contextos, também se possui o desafio do pluralismo religioso e de uma sociedade secular.

Isto posto, Dreyer percebe que uma maneira de pensar a tradução é justamente analisar os casos concretos em que essas traduções já acontecem, verificando onde e como que a mensagem cristã já é traduzida para dentro do espaço público. Trata-se do estudo da religião vivida no mundo da vida. Como pais colocam seus valores numa reunião de escola com pessoas de outras religiões, ou mesmo como que um cristão traduz sua fé num ambiente de trabalho plural. Nesses espaços, em que, de modo prático, já se executam traduções da fé cristã para uma linguagem pública (DREYER, 2011, p. 2).

O teólogo africano também entende existir consenso entre teólogos/as públicos/as acerca da necessidade de tradução do conteúdo teológico numa linguagem acessível ao espaço público. Contudo, o consenso não é o mesmo quando se avalia a forma que esta tradução deve tomar. Ele exemplifica esta dificuldade por meio das propostas distintas de tradução de Barth e Habermas. Para o primeiro, é necessária uma tradução da linguagem de Canaã para a dos jornais, apesar dele mesmo não apresentar como este trabalho de tradução deve ocorrer. Por sua prática teológica, contudo, sabe-se que exprimiu seu pensamento sempre desde uma linguagem bastante circunscrita ao público eclesial4. Por sua vez, o imperativo da tradução habermasiano traz o risco de que a mensagem cristã seja reduzida à argumentação pública, negligenciando a força pública dos desejos,

\footnotetext{
${ }^{4}$ Existem algumas elaborações instigantes em Barth como quando descreve a existência humana como co-humanidade, há aí, a nosso ver, base bastante pertinente para uma teologia pública que consiga dialogar com questões concretas sobre dignidade humana e direitos humanos. Mesmo aí, entretanto, se deve notar que seu ponto de partida é confessional e que mesmo o aquilo que chama de humano real, não é outra coisa senão a humanidade que toma forma em Jesus Cristo (cf. BARTH, 1978; ZEFERINO, 2018).
} 
rituais, emoções e convicções cristãs como expressas em atitudes de lideranças cristãs que por meio de manifestações públicas de fé demonstraram sua resistência ao apartheid (DREYER, 2011, p. 2-4).

Com base em Ricoeur, Dreyer (2011) percebe a possibilidade de tratar da tradução também no nível das relações intersubjetivas, entre identidade e alteridade, no trabalho de transferir significados de um contexto para outro (DREYER, 2011, p. 6). Assim, com esse pano de fundo ricoeuriano, o autor destaca cinco aspectos como pontos de partida para a tradução interlinguística de uma teologia pública:

1. A tradução é possível em virtude da diversidade de idiomas (religiões), sendo necessário reconhecer e respeitar essa diversidade (DREYER, 2011, p. 6).

2. A ênfase está nas traduções concretas e não numa discussão especulativa acerca da possibilidade da tradução e de uma linguagem comum. Julga-se, isto sim, a fidelidade que uma tradução mantém a um determinado entendimento da mensagem cristã. Ao se compreender a mensagem cristã como opção preferencial pelos pobres, por exemplo, este será o critério para verificar se esta mensagem foi fielmente traduzida para a arena pública. (DREYER, 2011, p. 6-7).

3. Faz parte do trabalho de luto abrir mão da ilusão de uma tradução perfeita da mensagem cristã e reconhecer as várias formas que esta tradução pode tomar. Aqui entra também a pluralidade artística de tradução da mensagem cristã por meio de pinturas, música, literatura, filmes, entre outros (DREYER, 2011, p. 7).

4. A vontade de ser uma testemunha cristã no mundo (desejo de traduzir) deve ser equilibrada com a abertura ao outro, ouvindo-o, respeitando-o, e aprendendo com ele. A hospitalidade linguística, como hospitalidade intercultural, pressupõe que "[...] o desejo de traduzir deve estar acompanhado com a disposição de descobrir os limites de suas próprias convicções religiosas e a disposição de verdadeiramente ouvir os outros". Nesse contexto, Dreyer cita Hogue, para quem o 
reconhecimento dos limites da tradição religiosa a que se pertence deve ser vista como uma oportunidade para aprender que nenhuma perspectiva domina a realidade toda, que múltiplas perspectivas proveem um quadro mais adequado de contextos específicos, e que aqueles e aquelas que estão mais vulneráveis em determinada realidade devem ser protagonistas na análise de suas situações (DREYER, 2011, p. 7).

5. O trabalho da tradução requer disposição para superar preconceitos e, inclusive, arriscar o encontro com o outro, aceitando a imperfeição de sua própria tradução. Isto se dá num contexto complexo, em que esta tradução não pode evitar as questões de classe, raça e gênero. Para ampliar a discussão deste ponto, em nota de rodapé, Dreyer cita Maluleke para quem aquelas não são simples diferenças horizontais, mas colocam as pessoas em papeis sociais muito desequilibrados, em que alguns sempre estão verticalmente acima e outros embaixo. Uns passam fome, e outros preferem vinho a cerveja, uns são senhores e outros são escravos, uns são deuses e outras dispensáveis, de que alguns vivem, já agora, no inferno e outros no céu. Não é a diferença entre o filho pródigo e o irmão mais velho, é a diferença entre o luxo do rico e a miséria de Lázaro. Para que essa realidade seja transformada, se necessita de algo muito mais radical do que a representação de um espaço público no horizonte do bem comum (DREYER, 2011, p. 7).

A tese de Dreyer é que toda teologia contextual requer a tradução da mensagem cristã para o espaço público com que dialoga. O oposto, poderia fazer concluir que uma teologia não contextual não somente não exige tradução, como a evita. A tradução é um movimento de abertura ao estranho, de familiaridade com o estranho, somente alguém que conheça dois idiomas é capaz de fazer a tradução entre elas.

Explicitadas as aplicações da hermenêutica ricoeuriana da tradução ao âmbito dos estudos da religião a partir de Taylor e Dreyer, percebe-se uma constante preocupação com o polo positivo e propositivo, construtivo dessas 
relações. No horizonte está a vontade da construção do bem comum, num diálogo entre religiões, e entre as religiões e a razão secular, que possibilite uma comunicação efetiva e frutífera. Entretanto, ao indicar o caminho da análise das traduções concretas da fé cristã para o espaço público, Dreyer nos leva a questionar acerca da possibilidade de se pensar a tradução também por meio do polo exclusivista.

Nas discussões da teologia do pluralismo religioso é comum que se separem as relações entre as religiões desde perspectivas, exclusivistas, inclusivistas e pluralistas. O diálogo e, com isso, a possibilidade da tradução interlinguística, estaria mais próxima do inclusivismo e do pluralismo. O próprio Dreyer observa existirem casos, como nos fundamentalismos, onde não apenas o aspecto contextual da teologia é negligenciado, como o esforço de tradução é visto como desnecessário. Não há vontade de diálogo, mas de imposição monológica da "verdade". A tradução pressupõe um diálogo e a disposição de ouvir o outro (DREYER, 2011, p. 3). No entanto, não nos parece o caso de nomear perspectivas exclusivistas como incapazes de tradução, mas, por meio da detecção das traduções concretas, tentar entender que tipo de traduções são essas. Assim, importa analisar a tradução da mensagem cristã que toma forma em preconceitos e violências nomeadas de "valores cristãos". Isto é, a tradução ética parece uma via profícua de acesso à epistemologia fundante de determinado discurso. Colocadas estas reflexões de fundo, adiante nos ocupamos da análise da tradução existente entre modelos democráticos elitistas e modelos teológicos exclusivistas.

\section{As democracias em crise e os modelos teológicos exclusivistas ${ }^{5}$}

Apesar de suas referências ao modelo político da ágora grega do quinto século antes da era comum, a democracia vigente, adjetivada como liberal, possui suas bases no projeto civilizacional moderno, construído sobre os alicerces da emancipação da razão, da revolução industrial e da revolução francesa (BOBBIO,

\footnotetext{
${ }^{5}$ Para este tópico utilizamos, de forma livre, com alterações e ulteriores desenvolvimentos, fragmentos da tese doutoral de um dos autores. Cf. (ANDRADE, 2020).
} 
1987, p. 149). Para os modernos, portanto, prevalecerá o conceito romano de republicanismo, relacionado à ideia de governo por representação no qual o governante tem seus poderes limitados temporalmente (BEÇAK, 2013, p. 7-8).

Alexis de Tocqueville (1805-1859), ao tratar da democracia na América, retrata o modo de organização sociopolítica que se instituíra nos Estados Unidos e o classifica como uma forma autêntica de democracia moderna, onde todos são iguais, não há privilégios hereditários, a interferência do poder estatal é mínima e inexiste aristocracia ou castas religiosas, sendo assegurada a participação ampla na vida política por meio da representação. Daí surgirão os partidos políticos, resultantes da convergência de interesses entre cidadãos e do desejo de representálos na esfera pública, e o sufrágio universal como mecanismo de escolha dos representantes. Assim, o exercício de um governo representativo passa a ser visto como ideal democrático moderno (BEÇAK, 2013, p. 9-11).

Sob o viés representativo e eleitoral, a democracia moderna teoricamente manteve a liberdade, a igualdade e o bem comum como seus pressupostos e, ao mesmo tempo, ideais a serem preservados e maximizados pelo exercício democrático. Assim, no seio de uma democracia todos os cidadãos são livres e são iguais em direitos e dignidade. Além disso, sabendo que o bem-estar da coletividade não coincide com o do indivíduo, “o indivíduo não deve impor sua vontade à comunidade, e esta não deve interferir nos assuntos privados de seus cidadãos” (TODOROV, 2012, p. 16).

A observação de Todorov remonta ao sistema preconizado na democracia grega. Bauman (2000, p. 92-93) lembra que entre os ambientes doméstico - oikos - e político - eclésia - os gregos situavam a ágora, responsável por garantir o tráfego suave e contínuo entre as duas esferas. O equilíbrio deste sistema de relação entre os interesses individuais e coletivo é o que garante a defesa contra as tentações do totalitarismo e do ultraliberalismo. 
Nos últimos tempos, entretanto, o sistema econômico hegemônico tornou a política sua refém. "As pressões de mercado estão substituindo a legislação política" (BAUMAN, 2000, p. 81). Os Estados "estão submetidos às agências privadas de classificação de riscos, que orientam suas escolhas, enquanto elas mesmas escapam a qualquer controle político" (TODOROV, 2012, p. 104). Há uma lógica de domínio do mercado sobre o Estado, que transformado em mínimo, esvazia as coletividades do bem público e bem comum, e desmobiliza as reivindicações da sociedade civil (BRIGHENTI, 2004, p. 19). Neste cenário, afirma Bauman (2000, p. 84), a democracia moderna não produziu maior liberdade individual, apenas transformou o cidadão político em consumidor de mercado e os pobres em consumidores frustrados. Isso afetou diretamente a crença nas promessas democráticas modernas de liberdade, igualdade e bem comum. Além de influenciar no modo como os indivíduos se relacionam com a política.

Desta conjuntura resultam ao menos duas situações que parecem manter relação entre si. A constatação de uma crise de representatividade, e consequentemente democrática, definida pela desconfiança e descrédito da população em relação aos seus representantes políticos, bem como a subserviência e dependência dos representantes eleitos a seus patrocinadores. E a ascensão dos assim chamados regimes híbridos, que apostam em saídas autoritárias como reação às frustrações ligadas à democracia moderna.

Ambos os fenômenos estão na pauta do dia e parecem apresentar uma relação diretamente proporcional. Na medida que cresce a insegurança e a complexidade no tocante aos valores democráticos, aumentam os discursos baseados em retóricas religiosas exclusivistas que defendem soluções rápidas e simplistas para a situação política. Além disso, o crescimento desses discursos aumenta a desconfiança da população em relação aos mecanismos democráticos. No interior dessa crise, está a relação entre modelos democráticos elitistas, aqueles cooptados pelo mercado, e modelos teológicos exclusivistas que dão base para 
saídas autoritárias, bem como preenchem os vazios de representatividade em virtude da confiança popular em relação às igrejas.

\subsection{Crise de representação}

De acordo com a Freedom House, uma organização sem fins lucrativos que monitora os índices democráticos em todo o mundo, 113 países sofreram declínio democrático desde 2006, enquanto apenas 62 apresentaram crescimentos nos índices de democracia. Em 2018, pelo $12^{\circ}$ ano consecutivo, de acordo com o relatório da organização, os países que sofreram reveses democráticos superaram os que registraram ganhos. Atualmente, apenas $45 \%$ dos países pesquisados apresentam índices de liberdade condizentes com a democracia liberal. Isso corresponde a 39\% da população mundial. Entre os demais países, 30\% são parcialmente democráticos e 25\% não democráticos (FREEDOM HOUSE, 2018; 2020).

Os dados possibilitam afirmar que a democracia moderna está em crise. Suas principais características, em especial o direito de escolher líderes em eleições livres e justas, liberdade de opinião e Estado de Direito, estão sob ataque e em declínio. Vários fatores têm influenciado esta crise democrática, que pode ser analisada sob diversos aspectos. Entretanto, nos parece central o fato da representatividade política estar sendo questionada por cidadãos de diversos países, conforme atesta o slogan "não me representa" que figurou em cartazes e palavras de ordem de inúmeras manifestações que se disseminaram por todo o globo desde o início da década de 2010, como aquelas da chamada primavera árabe, Occupy Wall Street (EUA), 15M (Espanha) e as passeatas de junho de 2013 no Brasil.

Luis Felipe Miguel (2014, p. 15-17, 30-31), elenca quatro grandes problemas da democracia representativa contemporânea: a separação entre governantes e governados; a formação de uma elite política distanciada da população; a ruptura entre a vontade dos representados e a vontade dos representantes; o 
distanciamento entre os compromissos assumidos em campanha eleitoral e o efetivo exercício do mandato. Mais do que elencar problemas de funcionamento, os quatro pontos destacados por Miguel tornam possível a constatação do colapso de uma das principais promessas da democracia moderna: a igualdade. Há de se frisar, contudo, que o desejo de igualdade nunca foi unanimidade entre os modernos e que a própria democracia liberal traz consigo o gérmen da desigualdade.

O pensamento elitista se desenvolveu no século XIX em oposição aos movimentos igualitários que almejavam "o desaparecimento de toda a diferença entre grupos humanos" (TODOROV, 2012, p. 50). De acordo com o fundador da teoria das elites, o filósofo político italiano Gaetano Mosca (1858-1941), a desigualdade é uma constante na sociedade, especialmente a desigualdade política, por isso uma minoria sempre dirigirá a maioria (MIGUEL, 2014, p. 31). Essa visão penetrou profundamente nas relações políticas da sociedade capitalista e disseminou a crença de que sempre haverá um pequeno grupo naturalmente capacitado para exercer o poder.

Vilfredo Pareto (1848-1923), um economista que se dedicou aos estudos sobre as interações elitistas, defendia a desigualdade como parte de uma ordem natural da sociedade. Segundo ele, as elites econômicas e as elites políticas constituem dois grupos historicamente em disputa pelo poder que se alternam no exercício político. (MIGUEL, 2014, p. 41-42). Esta concepção está na origem do pensamento fascista.

A convergência teórica entre elitismo e democracia surgiu com autores como Robert Dahl e Joseph Schumpeter, para os quais seria um risco à democracia deixar-se orientar pelas escolhas da população, visto que a própria noção de bem comum varia conforme distintos grupos e indivíduos, não sendo algo solucionável somente por meio da lógica (AVRITZER, 2000, p. 28).

Para o elitismo democrático, cabe à racionalidade elitista reduzir as opções daquilo que pode ser bom para a sociedade e submetê-las à avaliação da população, 
de forma que a opção mais votada será considerada a melhor alternativa política. Sendo assim, a democracia elitista será caracterizada pelo governo de elites que se alternam e são conduzidas ao poder por meio de eleições nas quais a população escolhe os mais capacitados para governar. (MIGUEL, 2014, p. 53). Em resumo, uma democracia representativa.

Com a consolidação do modelo democrático representativo, a perspectiva elitista de naturalização da desigualdade política parece ter se radicalizado e tornado o sistema não só insensível, mas fomentador das desigualdades que assolam toda a sociedade. Hoje, as desigualdades socioeconômicas alcançam níveis escandalosos em quase todas as partes do mundo. No Brasil, cuja herança colonial e escravista corrobora perspectivas elitistas, a desigualdade extrema se tornou uma característica do cenário nacional (cf. SOUZA, 2003). Dados da ONG OXFAM Brasil (2017) revelam que seis brasileiros - todos homens brancos - concentram a mesma riqueza que a metade mais pobre da população (100 milhões de pessoas). E os $5 \%$ mais ricos do país recebem por mês o mesmo que os demais 95\% juntos.

Um estudo da Fundação Getúlio Vargas (FGV), publicado em novembro de 2019, aponta que entre 2014 e 2019 a renda da metade mais pobre do país diminuiu $17,1 \%$ e a da classe média reduziu 4,16\%. Contudo, os $10 \%$ mais ricos tiveram sua renda aumentada em 2,55\%. E a renda das pessoas que compõem o $1 \%$ mais rico subiu 10,11\% (cf. NERI, 2019).

Diante desse cenário, $84 \%$ da população brasileira acredita que é obrigação dos governos diminuir as diferenças entre ricos e pobres, revela a OXFAM Brasil em parceria com o DATAFOLHA (2019). Todavia, 57\% não acreditam que as desigualdades diminuirão nos próximos anos, o que revela uma grande descrença na capacidade do poder político e, portanto, nos representantes. Daí decorre a atual crise de representação, pois os representantes eleitos não representam os interesses da maior parte da população e, com isso, os graves problemas sociais nem chegam a ser debatidos na arena política, ou seja, não são representados. 
A crise representativa coloca em xeque a própria democracia, pois o sistema cai em descrédito quando seu método falha no cumprimento das promessas de maior liberdade, igualdade e bem comum preconizadas pela democracia moderna. Isso torna a sociedade vulnerável a discursos de perfil messiânico, que se valem da frustração popular com a política para estabelecer vínculos emocionais com a população e tendem a fragilizar ainda mais a democracia, pois costumam adotar posturas autoritárias e práticas de controle que interferem na vida privada dos cidadãos.

\subsection{Regimes híbridos e democracias deficitárias: uma zona cinzenta}

O declínio democrático, impulsionado pelo crescente questionamento em relação à representação, tem sido acompanhado por outros fatores de risco à democracia moderna: o sentimento de que as democracias estão com problemas em termos políticos e econômicos, especialmente com a crise financeira de 2008; a autoconfiança e vitalidade renovada dos regimes autoritários, impulsionada por Rússia e China; a mudança no equilíbrio geopolítico, com um ambiente internacional marcadamente mais hostil às normas democráticas do que na década de 1990, o período unipolar dos EUA (PLATTNER, 2015, p. 8-10). Este cenário tem provocado a ascensão de um novo tipo de regime político, parcialmente avesso aos valores democráticos modernos, mas não totalmente identificado com o autoritarismo: os regimes híbridos.

Ainda que regimes híbridos não sejam propriamente novos, há uma novidade em sua fórmula atual. Enquanto, nos regimes totalitários do século XX, os métodos de controle político eram mais explícitos, como o banimento de partidos de oposição, o estabelecimento de limites sobre a organização da sociedade civil, em que a política partidária figurava dentro da estrutura de um único partido, os regimes de hoje sentem uma maior pressão de conformidade às normas democráticas, devendo exibir, ao menos, uma fachada institucional democrática. Todos os regimes deste tipo têm uma arena eleitoral deficiente, com autoridades eleitorais parciais e incompetentes para punir fraudes, falta de 
transparência na contagem de votos e monitoramento político, coação de eleitores e barreiras legais que dificultam a entrada na competição eleitoral e a liberdade para fazer campanha (DIAMOND 2015, p. 149-156).

Como já mencionado, o crescimento dos regimes híbridos deriva, dentre outros fatores, de um renovado ímpeto dos regimes autoritários, exibindo técnicas e métodos sofisticados para sufocar movimentos democráticos domésticos e, mais do que isso, desafiar a ordem política liberal internacional. De acordo com Diamond, Plattner e Walker (2016, p. 11), um "livro de regras" parece estar se difundido, sugerindo abordagens e técnicas comuns: leis que criminalizem fluxos internacionais de assistência técnica e financeira a partidos democráticos, movimentos, mídia, monitores de eleições, ONGs cívicas; criação de ONGs e monitores "zumbis", ou seja, a serviço do regime; criação mesmo de realidades alternativas por meio da mídia e da propaganda; além do controle das liberdades, por exemplo, na internet.

Tanto os índices da Freedom House (2018) como os da revista inglesa The Economist (2019; 2020), atestam que a democracia moderna está sendo agredida e enfraquecida. Segundo o relatório 2018 da Freedom House, Estados que, há uma década, pareciam promissoras histórias de sucesso - Turquia e Hungria, por exemplo - estão entrando em regime autoritário. Enquanto isso, as democracias mais poderosas do mundo estão atoladas em problemas aparentemente intratáveis em casa, incluindo disparidades sociais e econômicas, fragmentação partidária, ataques terroristas e um afluxo de refugiados que forçou alianças e aumentou o medo do "outro".

O The Economist Intelligence Unit's Democracy Index (2020), realizado desde 2006 pelo britânico Economist Group, editor da revista The Economist, classifica, com base em dados de 2019, a maioria dos países - 54,5\% - numa "zona cinzenta" entre as democracias plenas e regimes autoritários, denominando-os como democracias falhas (flawed) e regimes híbridos. Estes países correspondem a $58,7 \%$ da população mundial. 
Para o índice da The Economist 2018, que classificou 167 países de acordo com 60 indicadores organizados em cinco grandes categorias - processo eleitoral e pluralismo, funcionamento do governo, participação política, cultura política democrática e liberdades civis - apenas 4,5\% da população do mundo vive em uma "democracia plena", o que equivale a $12 \%$ dos países analisados. Os regimes autoritários representam $31,7 \%$ dos países analisados e governam 35,6\% da população mundial. Os dados de 2019 apontam um crescimento no número de democracias plenas para 5,7\% da população mundial e 13,2\% dos países. Os regimes autoritários, entretanto, também registraram um crescimento para 32,3\% dos países e 35,6\% da população mundial (THE ECONOMIST INTELLIGENCE UNIT, 2019; 2020).

Conforme o The Economist Intelligence Unit's Democracy Index (2019; 2020), na América Latina, apenas Uruguai, Costa Rica e Chile figuram entre as democracias plenas. A grande maioria dos países latino-americanos não são democracias consolidadas nem regimes autoritários. Na última década, a média do subcontinente apresentou um considerável declínio, de 6,43 pontos em 2008 para 6,13 em 2019, mantendo-se no limiar da classificação entre regimes híbridos e democracias imperfeitas. Isso se deve ao fato de que a maior parte dos países da região têm democracias frágeis, nas quais os níveis de participação política são baixos e a cultura democrática é fraca. Esta fragilidade fica ainda mais evidente diante dos recentes casos de interrupção de mandatos presidenciais na Bolívia (2019), no Brasil (2016), no Paraguai (2012) e em Honduras (2009). Apesar destas destituições de poder terem sido justificadas judicialmente, sobre todas pairam questionamentos que colocam em dúvida o status democrático destes países.

Apesar dos índices enquadrarem somente El Salvador, Bolívia, Honduras, Guatemala e Haiti na classificação de regimes híbridos, é possível afirmar que a maior parte dos Estados latino-americanos guardam características que os situam no limiar desta categoria, pois apesar de promoverem eleições e, guardadas as devidas proporções, a alternância de poder, neles "o crime e a violência são galopantes, a polícia demanda subornos e abusa dos direitos individuais, o Estado é 
corrupto e não responde a tempo, o poder judicial é fraco e horrivelmente influenciável” (DIAMOND, 2015, p. 210). Numa democracia superficial, sobretudo as minorias étnico-raciais e pessoas em situação de pobreza são as que mais sofrem em virtude dos elevados índices de violência, ineficiência e corrupção de órgãos do Estado e do poder judiciário (DIAMOND, 2015, p. 210). Compreende-se, portanto, que a efetivação democrática nos países latino-americanos é ainda deficitária ou parcial, ao que se destaca a ascensão dos assim chamados regimes híbridos.

No caso do Brasil, houve declínio democrático na última década, em 2008 o país apresentava um índice democrático de 7.38, caindo para 6.86 em 2017. $\mathrm{O}$ ano eleitoral de 2018 contribuiu para a subida do índice para 6.97. Entretanto, 2019 registra um retorno ao mesmo índice de 2017 (THE ECONOMIST INTELLIGENCE UNIT, 2019; 2020). O ambiente democrático foi atingido na passagem de 2014 para 2015, quando o país passou a sofrer os impactos da crise financeira internacional e assistiu ao início de uma grave crise política originada nas eleições presidenciais de 2014. Após uma disputa eleitoral acirrada e marcada por acusações de corrupção no primeiro governo de Dilma Rousseff (PT), o candidato derrotado, Aécio Neves (PSDB), pediu auditoria do pleito e colocou em dúvida o resultado das urnas (MATAIS; ROSA; BULLA, 2014). Na sequência, usufruindo da condição de senador da república, o ex-candidato adotou discursos agressivos, mobilizou manifestações contra o governo e prometeu deixar a presidenta6 "no chão" (NERY; GUERREIRO, 2014). Este movimento chegou, em 2016, a destituí-la de seu cargo por meio do seu impedimento. Entretanto, os esforços do agora deputado federal mineiro se somaram ao capital eleitoral colhido pelo representante da extrema direita Jair Bolsonaro, eleito presidente em 2018. Em 2020, o país enfrenta uma crise gravíssima com a pandemia do novo coronavírus que, aliada à crise política e econômica, se apresenta como um desafio sem precedentes na história democrática do país.

\footnotetext{
${ }^{6}$ A palavra "presidenta", apesar de questionada, consta no Vocabulário Ortográfico da Língua Portuguesa da Academia Brasileira de Letras (cf. VOLP, 2021) e designa a "mulher que é a chefe de governo de um país de regime presidencialista", segundo o dicionário Michaelis (2021). Trata-se do emprego feminino do substantivo biforme derivado do verbo "presidir". De acordo com Schwindt (2020, p. 14), uma das razões para a estranheza em relação ao termo "é a natureza híbrida do sufixo -nte, resquício do particípio presente latino que sobrevive no português como morfema derivacional responsável por formar nomes a partir de verbos". Não obstante, a utilização da flexão de gênero marca um posicionamento linguístico inclusivo que acompanha as transformações culturais, manifestado na opção da senhora Dilma Vana Rousseff para designar seu cargo durante o mandato presidencial no período de 2011 a 2016.
} 


\subsection{0 assédio teocrático}

Boa parte dos países latino-americanos que se encontram na zona cinzenta dos índices democráticos apresentaram nos últimos anos algum tipo de radicalização religiosa na esfera pública7. No Brasil, a forte presença de discursos religiosos no campo político ficou notória durante o processo de votação do Impeachment de Dilma Rousseff, em 2016 - transmitida ao vivo pela TV aberta. Vários deputados proferiram o nome de Deus e evocaram os valores da família tradicional para justificar o voto pela deposição da chefe do poder executivo ${ }^{8}$. Este movimento se sacramentou na candidatura e posterior vitória de Jair Messias Bolsonaro nas eleições de 2018, que adotou como lema político e nome de sua coligação "Brasil acima de tudo, Deus acima de todos". Ronaldo de Almeida, importante intérprete das relações entre religião e política, percebe a importância dos evangélicos naquela campanha eleitoral, bem como destaca na narrativa de Bolsonaro uma linguagem própria para se comunicar com tal público: "Narrou a facada que sofreu sob a forma de um testemunho evangélico. Seu primeiro pronunciamento como presidente eleito foi precedido por uma típica oração evangélica" (ALMEIDA, 2019, p. 36).

Apesar da força que as igrejas pentecostais e neopentecostais vêm apresentando nas últimas eleições brasileiras, é necessário observar um deslocamento histórico da posição de que "crente não é deste mundo, por isso não se envolve em política”, do início da década de 1980, para a ideia, com o advento da Assembleia Constituinte, de que "irmão vota em irmão". Assim, surge a primeira

\footnotetext{
${ }^{7}$ Em 2015, a Guatemala elegeu como presidente o comediante Jimmy Morales, de cunho conservador e religioso, cuja campanha foi pautada pelo discurso contra o aborto, contra o casamento homossexual e contra a legalização da maconha (cf. MARTínEZ AHRENS, 2015). Em 2016, o voto evangélico foi determinante para a rejeição do acordo de paz com as Forças Armadas Revolucionárias da Colômbia (FARC) posto em plebiscito pelo governo colombiano e considerado contrário aos "valores da família tradicional" pelos líderes evangélicos daquele país (cf. MARCOS, 2016). Em 2018, a aliança do esquerdista Andrés Manuel López Obrador com o Partido do Encontro Social (PSE), de raízes evangélicas, foi fundamental para a sua vitória nas eleições presidenciais mexicanas (cf. ROJAS, 2018). Já em 2019, o discurso cristão e o uso da Bíblia permearam toda a crise política boliviana que resultou na renúncia do indígena Evo Morales e a ascensão da direitista Jeanine Áñez (cf. REDAÇÃO, 2019).

${ }^{8}$ Em vídeo disponível no Canal da Câmara dos Deputados no YOUTUBE (2016) com quase dez horas de duração, sendo seis delas para a votação do impeachment, é possível assistir as argumentações dos votantes que inúmeras vezes justificavam seu voto por Deus e pela família, mas, em geral, não tratavam do objeto em discussão na votação. Exemplifica o ambiente daquela reunião da assembleia o voto de Jair Messias Bolsonaro que, na época, além de exaltar a ditadura militar e enaltecer um torturador que esteve envolvido em violências contra Dilma no período em que estava presa pela ditadura, também já bradava aquele que viraria seu lema na campanha eleitoral: "Por um Brasil acima de tudo e por Deus acima de todos o meu voto é sim".
} 
bancada evangélica, marcando uma nova forma de presença cristã nesse contexto. Em 2003, a bancada dá origem à Frente Parlamentar Evangélica, apoiada fortemente pela Assembleia de Deus e pela Igreja Universal do Reino de Deus, que começavam a tornar visíveis seus projetos políticos 9 por meio da ocupação de cargos públicos e da atuação partidária, principalmente no Partido Social Cristão (PSC) e no Partido Republicano Brasileiro (PRB, atual Republicanos) ${ }^{10}$, respectivamente. Apesar do seu ativismo contra projetos considerados ofensivos à moralidade religiosa, esta nova frente não representava um levante conservador naquele período (CUNHA, 2018, p. 39-41).

É em 2010 que se inicia a potencialização da força fundamentalista cristã no Brasil. Dentre os fatores que influenciaram esta situação, destaca-se o processo de construção do Plano Nacional de Direitos Humanos-3, que ampliava os direitos da população LGBTQIA+ e pautava a legalização do aborto, o que provocou a ira de alguns grupos cristãos historicamente contrários a estas pautas. Emerge deste contexto uma forte coalizão em “Defesa da Família Tradicional”, liderada por pentecostais e neopentecostais e apoiada por muitos católicos tradicionalistas e carismáticos, que levaria o pastor Marco Feliciano (à época no PSC e hoje no Republicanos) à presidência da Comissão de Direitos Humanos e Minorias da Câmara dos Deputados em 2013; o pastor Everaldo Dias Pereira (PSC-RJ) à candidatura para a presidência da república nas eleições de 2014; e o evangélico Eduardo Cunha (PMDB-RJ) à presidência da Câmara Federal em 2015. (CUNHA, 2018, p. 40-42). Com isso, "uma série de pautas garantidoras da moralidade religiosa puritana, sob o rótulo de 'defesa da família', ganhou espaço [...] e mais espaço foi dado para pautas relativas a privilégios à atuação pública das igrejas” (CUNHA, 2018, p. 42)11.

\footnotetext{
${ }^{9}$ Edir Macedo, líder da Igreja Universal do Reino de Deus, principal representante institucional do neopentecostalismo e da teologia da prosperidade, é bastante explícito em obra de 2008 ao relatar seu plano de poder político por meio da mobilização dos evangélicos (MACEDO; OLIVEIRA, 2008).

${ }^{10} \mathrm{O}$ partido já teve em seu quadro um vice-presidente no governo Lula, José Alencar.

${ }^{11}$ De acordo com Dantas (2011, p. 321), que pesquisou largamente o perfil da bancada religiosa no Congresso nacional, a ação deste grupo consiste em promover "mecanismos de naturalização da realidade, universalização de leis particulares, justificação da ordem estabelecida e legitimação do poder dominante".
} 
O fortalecimento da chamada bancada da Bíblia acompanhou o crescimento demográfico de evangélicos no país e fez emergir dentre a opinião pública o discurso conservador que até então se apresentava tímido ou acuado. As mídias religiosas alimentaram o imaginário de perseguição contra os valores cristãos e o consequente combate contra militantes LGBTQIA+, feministas e partidos de esquerda, cujo projeto estaria supostamente voltado a implantação do comunismo e supressão da religião. Esse discurso fundamentalista e belicoso promoveu a aproximação e confluência de interesses com grupos conservadores e corporativistas, o que resultou, por exemplo, na configuração da bancada BBB (Boi, Bala e Bíblia) no Congresso Nacional, que reúne representantes do agronegócio, da segurança pública e da indústria armamentista e de grupos cristãos fundamentalistas. Entre outros fatores que contribuíram para a consolidação da força evangélica no campo político, destaca-se o espírito messiânico da Operação Lava Jato com o suporte da Força Tarefa do Ministério Público Federal liderada por Deltan Dallagnol. (CUNHA, 2018, p. 42-43). O procurador, membro da Igreja Batista, já demonstrou conviç̧ão de que a sua atuação "é uma missão cristã" (AGÊNCIA PÚBLICA, 2019).

O cenário político atual demonstra que as tendências teocráticas já não podem ser consideradas teorias da conspiração ou mera figura de linguagem. Já não se trata mais de mero posicionamento contra o aborto, o casamento gay e a legalização das drogas. Agora, o que está em jogo é um verdadeiro projeto de poder, cuja "estratégia política para o sucesso torna-se a de elevar os tons da conflitualidade, exagerar a desordem, agitar os ânimos do povo com a projeção de cenários inquietantes para além de todo realismo"12 (SPADARO; FIGUEROA, 2017).

\footnotetext{
${ }^{12}$ O momento corrente também parece refletir aquilo que Boaventura de Sousa Santos (2014), em sua tipologia de teologias políticas, chama de teologias fundamentalistas e tradicionalistas que tendem à manutenção do poder instituído ou ainda, o que parece estar sendo gestado no país, a tentativa de substituição de um regime hegemônico por outro, neste caso uma forma teocrática, mesmo que subterrânea, de organização política.
} 
As características de defesa da moral cristã, da fé e da prosperidade podem ser recebidas (traduzidas) de maneira bastante confortável para um público católico alinhado com os princípios da tradição, família, propriedade e neocristandade ${ }^{13}$. Este modelo teológico exclusivista, que adota uma postura apologista diante das mudanças da modernidade, tem voltado com força no catolicismo, acompanhado de muito dinheiro, poder e visibilidade, além de uma postura triunfalista que reivindica a defesa da fé, da ortodoxia, da moral cristã e da tradição (BRIGHENTI, 2015, p. 26). É justamente esta corrente tradicionalista que tem se unido ao fundamentalismo evangélico formando uma espécie de "ecumenismo do conflito que os une no sonho nostálgico de um Estado de traços teocráticos" (SPADARO; FIGUEROA, 2017). Juntos, católicos integralistas ${ }^{14}$ e evangélicos fundamentalistas, colocam em curso uma espécie de neocristandade pós-moderna que condena a secularização e evoca a suplantação do projeto da modernidade ${ }^{15}$. O medo do pluralismo e do outro como distinto de mim $^{16}$, levam a uma postura de enrijecimento institucional e identitário com apelo apologista e dogmatista, pautadas, não por último, numa leitura literalista da tradição bíblica (BRIGHENTI, 2004, p. 25).

Antonio Spadaro e Marcelo Figueroa (2017), o primeiro jesuíta e o segundo pastor presbiteriano, destacam três características do atual fenômeno teopolítico fundamentalista cristão: o maniqueísmo político, a teologia da prosperidade e a

\footnotetext{
13 “O tradicionalismo e o fundamentalismo são sempre um fenômeno ligado às elites, a uns poucos abastados. Nos dois pontificados anteriores ao atual, os movimentos eclesiais com perfil de neocristandade foram vistos como a 'nova primavera da Igreja'. Entretanto, na prática, revelaram-se os principais responsáveis pelo atual 'inverno eclesial', que o novo pontificado se propõe superar. A pastoral apologista assume a defesa da instituição católica diante de uma sociedade anticlerical e a guarda das verdades da fé em face de uma razão secularizante, que não reconhece senão o que pode ser comprovado pelas ciências. Ao desconstrucionismo dos metarrelatos e do relativismo reinante que geram vazio, incertezas e medo, contrapõe-se o 'porto de certezas' da tradição religiosa e um elenco de verdades apoiadas numa racionalidade metafísica” (BRIGHENTI, 2015, p. 26).

${ }^{14}$ A versão brasileira do integrismo ou integralismo católico, com influência do integralismo de Plínio Salgado, é sistematizada por Plínio Corrêa de Oliveira dando origem ao movimento Tradição, Família e Propriedade (cf. ZANOTTO, 2020; CHISTOFOLETTI, 2010). Este modelo teológico antimoderno se constitui, no século XX, em crítica reacionária ao Concílio Vaticano II (cf. PIERUCCI, 1992). O integralismo católico tem se unido ao fundamentalismo evangélico em virtude de convergências pragmáticas (cf. FAGGIOLI, 2017; SPADARO e FIGUEROA, 2017; GONÇALVES, 2012).

${ }^{15}$ A crítica à modernidade é também corrente em grupos de distinta perspectiva política, como é o caso dos estudos decoloniais que compreendem existir na modernidade uma amálgama com o colonialismo, de tal modo que a expansão moderna se torna também expansão colonial, não apenas econômica, mas também epistemológica (cf. GROSFOGUEL, 2008, sobretudo a discussão sobre transmodernidade a partir de Dussel). Este tipo de crítica não possui relação com aquele outro fenômeno antimoderno integrista e fundamentalista. No entanto, essas perspectivas partem da compreensão de que há problemas estruturais no projeto da modernidade.

16 "Fundamentalistas vivem para testemunhar sua verdade: a verdade do outro está aí para ser ou convertida ou eliminada - o que não deixa de ser a negação da condição humana para aquele que pensa de forma diferente" (CAMPOS, 2014, p. 482-483; cf. também CAMPOS, 2018).
} 
defesa da liberdade religiosa. (1) O maniqueísmo político subdivide a realidade entre o Bem absoluto e o Mal absoluto ${ }^{17}$. Visa combater as ameaças aos valores cristãos e esperar a iminente justiça do Armagedon, uma prestação de contas entre o Bem e o Mal, entre Deus e Satanás. Nesse sentido, a comunidade dos fiéis tornase a comunidade dos combatentes. Para sustentar o conflito, se baseiam em leituras descontextualizadas dos textos veterotestamentários sobre a conquista do "Deus dos exércitos" e sobre a defesa da terra prometida. Essas atitudes se baseiam nos princípios fundamentalistas do início do século $\mathrm{XX}$, que gradualmente se radicalizaram $^{18}$. (2) A teologia da prosperidade representa uma característica fundamental do movimento teocrático cristão. Trata-se do anúncio e assimilação de um "evangelho da prosperidade", propugnado principalmente por organizações missionárias com uma forte influência religiosa, social e política, em seu entendimento "Deus quer que os fiéis estejam fisicamente saudáveis, materialmente ricos e pessoalmente felizes". (3) $\mathrm{O}$ terceiro elemento diz respeito à forma peculiar de proclamação da defesa da "liberdade religiosa", percebida como um desafio frontal e direto à laicidade do Estado. Pode-se considerar esta pauta como possível subterfúgio legal para legitimação de discursos preconceituosos

\footnotetext{
${ }^{17}$ Cabe comentar que o texto de Spadaro e Figueroa, originalmente publicado em La Civiltà Cattolica, reflete de forma especial a configuração do cristianismo estadunidense. Nesse contexto, é importante trazer à tona a noção de destino manifesto. Ainda que a modernidade tenha promovido a separação entre religião e política, a principal nação democrata enaltecida por Tocqueville - os Estados Unidos da América - se desenvolveu em torno de uma doutrina religiosa: o destino manifesto. $O$ termo utilizado pela primeira vez em meados do século XIX por John O'Sullivan sintetiza a doutrina de vertente puritana calvinista, já presente entre os colonos estadunidenses do séc. XVII: "Deus escolheu a América para que aqui se construísse a sede do paraíso terrestre, por isso, a causa da América será sempre justa e nada de mal jamais lhe será imputado. Os colonos são os verdadeiros herdeiros do povo eleito, pois prestavam a Santa Fé. Nossa missão é liderar os exércitos de luz em direção aos futuros milênios" (Pregações Puritanas, 1660 apud SILVA, 2010, p. 57). O destino manifesto faz com que não seja mera coincidência o fato do American way of life - estilo de vida americano - orientar boa parte do imaginário capitalista contemporâneo. Neste sentido, em função da influência ideológica, apoiada por relações econômicas e políticas, a conjuntura estadunidense tende a interferir diretamente no contexto político-cultural de vários países, em especial da América Latina. Sobre o tema ver o artigo de Aya Smitmans (2007) intitulado Ideales democráticos, religión y el destino manifesto en la política exterior de los Estados Unidos.

18 "O termo 'fundamentalismo evangélico', que hoje pode se assemelhar a 'direita evangélica' ou 'teoconservadorismo', tem as suas origens nos anos 1910-1915". A publicação dos volumes de The Fundamentals: a testimony to the truth, represetavam uma resposta "à 'ameaça' das ideias modernistas da época [...]". O fundamentalismo cristão atual deriva do reconstrucionismo cristão (dominionismo), encampado pelo pastor Rousas John Rushdoony (1916-2001), com o objetivo de submeter o Estado à fé cristã. Entre os influenciados por essa teoria se pode contar o assessor de Trump, Steve Bannon (SPADARO; FIGUEROA, 2017, cf. também VERDÚ, 2018). O movimento fundamentalista do final do século XIX e início do século XX tinha, portanto, como fundamentos uma noção de inerrância bíblica; o caráter inegociável da divindade de Cristo; o nascimento virginal; a morte vicária de Jesus e sua ressurreição; à espera da ressurreição na carne e a parusia (segunda vinda de Cristo) (CAMPOS, 2012, p. 328). No contexto brasileiro, Campos (2012, p. 334) ainda relaciona o fundamentalismo àquilo que Rubem Alves chama de Protestantismo da Reta Doutrina que acredita que a salvação humana depende das fórmulas doutrinárias corretas.
} 
disfarçados de liberdade religiosa ${ }^{19}$.

Evangélicos e católicos adeptos desta tendência teocrática e produtores de uma teologia política de legitimação do poder instituído, condenam o diálogo ecumênico tradicional. Entretanto, em virtude de suas equivalências em aspectos morais ${ }^{20}$, e seletivamente também confluências hermenêutico-teológicas, acontece uma aproximação (tradução) entre fundamentalistas evangélicos e católicos integralistas que está ocupando cada vez mais espaço na esfera política. Para este ecumenismo do ódio, como nominam Spadaro e Figueroa (2017), "a intolerância é marca celestial de purismo, o reducionismo é metodologia exegética, e o ultraliteralismo é a chave hermenêutica”.

Percebe-se, assim, que contextos de regime híbrido e de democracia deficitária, parecem ser propícios ao avanço das pautas de grupos políticos que possuem em sua fundamentação modelos teológicos exclusivistas e de prosperidade. É neste sentido que fé cristã e democracias elitistas ${ }^{21}$ se encontram num jogo de convergências pragmáticas.

\footnotetext{
${ }^{19}$ É no mínimo curioso que o Deputado Federal de São Paulo, do Partido Republicanos, Celso Russomano, apresente um projeto de lei nacional sobre liberdade religiosa, o PL 6238/2019. Em seu artigo primeiro, à distinção da Constituição Federal, inclui a liberdade de discurso religioso na esfera pública. As consequências práticas desse tipo de formulação são evidentes num país em que preconceitos vários resultantes de uma fundamentação religiosa não apenas se multiplicam, como geram vítimas reais. Basta considerar os atentados a espaços destinados a práticas religiosas de matriz africana, ou mesmo os constantes ataques sofridos pela população LGBTQIA+. A liberdade religiosa, bem como a liberdade de expressão são asseguradas pela carta constitucional (1988), fazendo com que um documento específico sobre liberdade de discurso religioso no espaço público seja recebido ao menos com alguma suspeita. $O$ PL está apensado a outros projetos como o PL 4356/2016 de autoria de Atila Nunes do PSL/RJ que busca criar o estatuto da liberdade religiosa; este, por sua vez, está apensado ao PL 1089/2015 de Josué Bengtson do PTB/BA que visa assegurar o livre exercício da liberdade religiosa, de expressão e de consciência; e o PL 6314/2005 cujo autor é Takayama do PMDB/PR que versa sobre a exclusão do crime de injúria e difamação quando for opinião de professor ou ministro religioso.

${ }^{20}$ A pauta conservadora, da qual evangélicos e católicos participam, além das discussões que possuem mais propaganda como a batalha contra o que denominam de "ideologia de gênero", assume também outras causas bastante ligadas ao punitivismo como a redução da maioridade penal e a reação à política de desarmamento (cf. ARAGUSUKU, 2018; ALMEIDA, 2017; LACERDA, 2018).

${ }^{21}$ Glauco Barsalini tece uma crítica relevante ao modelo democrático que se implementou no país, percebendo suas limitações em virtude da incapacidade de desvencilhamento de um poder soberano não afeito aos valores que se poderiam esperar de uma democracia plena. Para ele, "O poder soberano, no Brasil, é unitário, autoritário e violento. Aqui, os que criaram as regras podem, livremente, intervir nelas a qualquer momento e, até, criar novas regras. Mas esses protagonistas do poder nunca se confundiram com o povo: são, eles, uma oligarquia, hábil em disseminar, de modo muito eficaz, o espírito de sua mentalidade - o moralismo e a disposição pela criminalização dos pretos, das mulheres, dos retirantes, dos índios, dos pobres, dos LGBT+, sempre acompanhada pelo sistemático e irrestrito modus operandi excludente e violento de seus juízes e de sua polícia" (BARSALINI, 2020, p. 115).
} 


\section{Conclusão}

A compreensão da necessidade de tradução nos estudos em teologia pública vem se consolidando em nível global. Seja pela necessidade de adequação da linguagem teológica a seus públicos (TRACY, 2006), pela exigência de uma espécie de habilidade bilíngue do fazer teológico (BEDFORD-STROHM, 2014), ou mesmo, como demonstrou Dreyer (2011), pela grande relevância da análise das traduções que já acontecem. Diante da tarefa de tradução colocada pela questão religiosa na atualidade, em seu polo crítico-analítico, a teologia pública se desenvolve acompanhada da teologia política e demais modos de investigação das relações entre religião e espaço público.

As traduções com as quais nos ocupamos aqui são aquelas que acontecem por grupos religiosos de escopo exclusivista-autoritário que imprimem na esfera política suas agendas privadas. Nesse sentido, pode-se falar de uma tradução moral da fé cristã que defende a família por meio do combate ao que denominam de "ideologia de gênero"; assume pautas punitivistas como a diminuição da maioridade penal e apoia o armamento; promove iniciativas de diminuição do poder estatal em favorecimento do mercado. Para utilizar a distinção de hermenêuticas indicada por Dreyer, pode-se dizer que existe aqui uma tradução interlinguística, da fé cristã para o espaço público, mais especificamente, de uma perspectiva exclusivista e de caráter teológico de prosperidade com um espaço público dominado por um sistema de mercado que instrumentaliza o ambiente democrático desde uma lógica elitista. A tradução intralinguística, por sua vez, tem lugar dentro do campo cristão. É aí que evangélicos fundamentalistas e católicos integristas se reconhecem.

No polo crítico-propositivo da teologia pública, ao assumir a metáfora da religião como idioma, explorada por Taylor, se faz necessária uma reflexão interna ao mundo teológico cristão brasileiro: Como é isso que por mais que eu fale o mesmo idioma que meu compatriota, nós não nos entendemos? Como é isso que quando digo "profecia", uns entendem que se trata de um oráculo adivinhatório, 
predição do futuro e outros compreendem como crítica social? Como é isso que quando leio "amarás o teu próximo como a ti mesmo", alguns compreendem como um chamado de amor ao próximo que é igual a si mesmo e que este amor deve se desdobrar na conversão do outro no mesmo, e outros entendem a gravidade de se perpetuar sistemas que oprimem e condenam pessoas à morte? Como é isso que quando digo "a verdade vos libertará”, uns se apropriam de uma sentença normativa que extermina quem não se enquadra e outros reconhecem sua incapacidade de compreensão total da realidade? Como é isso que quando leio "tive fome e me destes de comer”, uns culpam quem está com fome e outros, além de partilhar o pão, ainda questionam que tipo de sociedade é esta que permite que tal situação se perpetue? Como é isso que quando se diz "Pai nosso", uns o privatizam, e outros compreendem a solidariedade como missão? Sim, há uma importante questão hermenêutica nisso tudo, mas na mesma medida, há também que se problematizar os afetos. Traduzir é também sentir.

Eventos recentes mais uma vez demonstraram as equivalências entre modelos teológicos exclusivistas evangélicos e católicos e sua conexão com uma teologia da prosperidade ${ }^{22}$. Numa releitura bíblica, poderia se falar de mercadores do templo que são simultaneamente sumo-sacerdotes, que comovem multidões em sua amálgama político-religiosa e condenam justas e justos à crucificação. Condenadas e condenados às valas do esquecimento, donde sua voz só poderá ser ouvida se sentida por quem ficou. Ricoeur (2006) fala da dívida moral que temos com as vítimas, de que é necessário contar suas histórias para que algozes sejam nomeados, vítimas não sejam culpabilizadas, e a memória não seja manipulada. A memória do sofrimento, quando negligenciada, traz o risco da repetição. Bonhoeffer (2009), numa lógica litúrgica, fala da confissão dos pecados e posterior perdão, mas também nos informa de que a confissão só é possível quando o pecado

\footnotetext{
${ }^{22}$ Duas situações exemplificam esta relação entre conservadorismo e prosperidade e suas relativas traduções, a saber, a oração em favor do Brasil de representantes evangélicos junto ao presidente; e a reunião de representantes de canais de TV de inspiração católica também com o chefe do executivo em busca de apoio para seus empreendimentos (FRAZÃO, 2020). O vídeo do apoio evangélico está disponível no canal do Youtube de seu porta-voz, Silas Malafaia (YOUTUBE, 2020); sobre o assunto cf. Sem fiéis, sem dízimo, sem palanque: epidemia esvazia templos, e igrejas neopentecostais não conseguem pagar horários alugados em emissoras de TV (NASCIMENTO, 2020). A notícia ligada ao campo católico teve grande repercussão, gerando notas de esclarecimento, a CNBB se posicionou dizendo que "A Igreja Católica não faz barganhas" (COMISSÃO ESPICOPAL PASTORAL PARA A COMUNICAÇÃO CNBB; REDE CATÓLICA DE RÁDIO; SIGNIS BRASIL, 2020; cf. também SBARDELOTTO, 2020; LORO, 2020; SMYDA, 2020).
} 
é reconhecido. Seja em virtude da crise sanitário-político-econômica atual provocada pelo novo coronavírus, ou pelo reconhecimento de tantas outras injustiças que tomaram lugar no contexto brasileiro, sobretudo contra as pessoas mais pobres, parece necessário admitir que não avançamos, ainda não é tempo de perdão, é tempo de denunciar as injustiças, demonstrá-las cientificamente, profeticamente apontar onde dói, teologicamente discernir os espíritos, e francamente dizer que estes sacerdotes-mercadores e seu ídolo do momento não adoram o mesmo Deus que aqueles e aquelas que se engajam com o sofrimento das pessoas mais vulneráveis.

\section{REFERÊNCIAS}

AGÊNCIA PÚBLICA. De olho em vaga no Senado em 2022, Dallagnol mirou apoio de evangélicos. Carta Capital, 23 set. 2019. Disponível em:

https://www.cartacapital.com.br/politica/de-olho-em-vaga-no-senado-em-2022dallagnol-mirou-apoio-de-evangelicos/. Acesso em: 21 jul. 2020.

ALMEIDA, Ronaldo de. A onda quebrada - evangélicos e conservadorismo. Cadernos Pagu, Campinas, n. 5O, p. 1-27, 2017.

ALMEIDA, Ronaldo de. Deus acima de todos. In: ABRANCHES, Sérgio et al. Democracia em risco? 22 ensaios sobre o Brasil hoje. São Paulo: Companhia das Letras, 2019. p. 3551.

ANDRADE, Rodrigo de. Ecumenismo e democracia: a contribuição teológica e democrática do ecumenismo de serviço no Brasil. 2020. Tese (Doutorado em Teologia) Pontifícia Universidade Católica do Paraná, Curitiba, 2020.

ARAGUSUKU, Henrique Araujo. O discurso da "ideologia de gênero" na Câmara dos Deputados: análise crítico-discursiva e psicopolítica. 2018. Dissertação (Mestrado em Psicologia Social) - Universidade de São Paulo, São Paulo, 2018.

AVRITZER, Leonardo. Teoria democrática e deliberação pública. Lua Nova: revista de cultura e política, São Paulo, n. 50, p. 25- 46, 2000.

AYA SMITMANS, María Teresa. Ideales democráticos, religión y el destino manifestó en la política exterior de los Estados Unidos. Oasis, Colombia, n. 12, p. 143-157, 2007.

BARROS, Douglas. Atuação teológico-política exclusivista: confrontos em torno de direitos e religião no Brasil contemporâneo. In: SOTO, Boris Briones; HIJERRA, Stefanie Butendieck; CAU, Cremildo António; OPAZO, Andrea Mosález (org.). Breviario multidisciplinario sobre el fenómeno religioso. Buenos Aires: Clacso, 2019. p. 310326. 
BARSALINI, Glauco. Religião, violência e política no Brasil: vivemos em uma democracia ou em um estado de exceção? Interações, Belo Horizonte, v. 15, n. 1, p. 108-120, jan.-jun. 2020.

BARTH, Karl. The church dogmatics: the doctrine of creation. Edinburgh: T \& T Clark, 1978. v. III.1.

BAUMAN, Zygmunt. Em busca da política. Rio de Janeiro: Jorge Zahar, 2000.

BEÇAK, Rubens. Democracia moderna: sua evolução e o papel da deliberação. Revista de Informação Legislativa, Brasília, v. 50, n. 199, p. 7-23, jul.-set. 2013.

BEDFORD-STROHM, Heinrich. Teologia Pública e responsabilidade política. Estudos Teológicos, São Leopoldo, v. 54, n. 1, p. 84-98, jan.-jun. 2014.

BOBBIO, Norberto. Estado, governo, sociedade: por uma teoria geral da política. Rio de Janeiro: Paz e Terra, 1987.

BONHOEFFER, Dietrich. Ética. Compilado e editado por Eberhard Bethge. São Leopoldo: Sinodal, 2009.

BRASIL. Constituição da República Federativa do Brasil de 1988. Disponível em: http://www.planalto.gov.br/ccivil_03/constituicao/constituicao.htm. Acesso em: 17 jul. 2020.

BRASIL. Projeto de Lei no 1089, de 2015. Assegura o livre exercício da liberdade religiosa, de expressão e de consciência. Disponível em:

https://www.camara.leg.br/propostas-legislativas/1199299. Acesso em: 17 jul. 2020.

BRASIL. Projeto de Lei no 4356, de 2016. Cria o estatuto da liberdade religiosa e dá outras providências. Disponível em: https://www.camara.leg.br/propostaslegislativas/2076943. Acesso em: 17 jul. 2020.

BRASIL. Projeto de Lei no 6238, de 2019. Institui a Lei Nacional de Liberdade Religiosa. Disponível em: https://www.camara.leg.br/propostas-legislativas/2231172. Acesso em: 17 jul. 2020.

BRASIL. Projeto de Lei no 6314, de 2005. Acrescenta inciso ao art. 142 da Lei ${ }^{0}$ 2.848, de 7 de dezembro de 1940 - Código Penal. Excluindo o crime de injúria e difamação quando for a opinião de professor ou ministro religioso. Disponível em:

https://www.camara.leg.br/propostas-legislativas/308517. Acesso em: 17 jul. 2020.

BRIGHENTI, Agenor. A ação pastoral em tempos de mudança: modelos obsoletos e balizas de um novo paradigma. Vida Pastoral, São Paulo, v. 56, n. 302, p. 23-34, 2015.

BRIGHENTI, Agenor. A Igreja perplexa: a novas perguntas, novas respostas. São Paulo: Paulinas, 2004. 
CAMPOS, Breno Martins. A exclusão do outro na história do mesmo: uma tentativa nova de classificar o velho fundamentalismo religioso. Religare, Paraíba, v. 15, n. 2, p. 354-381, 2018.

CAMPOS, Breno Martins. A linhagem do fundamentalismo protestante no século XX: das raízes às últimas ramificações. Interações, Belo Horizonte, v. 9, n. 16, p. 469-484, jul.dez. 2014.

CAMPOS, Breno Martins. O fundamentalismo como um limite à relativização do campo religioso. In: OLIVEIRA, Kathlen Luana de et al. Religião, política, poder e cultura na América Latina. São Leopoldo: EST, 2012. p. 325-335.

CHRISTOFOLETTI, Rodrigo. A enciclopédia do integralismo: lugar de memória e apropriação do passado (1957-1961). 2010. Tese (Doutorado em História, Política e Bens Culturais) - Fundação Getúlio Vargas, Rio de Janeiro, 2010.

COMISSÃO ESPICOPAL PASTORAL PARA A COMUNICAÇÃO CNBB; REDE CATÓLICA DE RÁDIO; SIGNIS BRASIL. Nota de Esclarecimento, 6 jun. 2020.Disponível em: https://www.cnbb.org.br/wp-content/uploads/sites/32/2020/o6/Nota-deEsclarecimento-CNBB-Comunicac\%CC\%A7a\%CC\%830-Signis-e-RCR.pdf. Acesso em: 10 jun. 2020.

CUNHA, Magali do Nascimento. Religião e política: fundamentalismos evangélicos no Brasil contemporâneo e suas expressões pelas mídias. In: KUZMA, Cesar; CAPPELLI, Marcio (org.). Religião, ética e política. São Paulo: Paulinas, 2018.

DANTAS, Bruna Suruagy do Amaral. Religião e política: ideologia e ação da "Bancada Evangélica” na Câmara Federal. 2011. Tese (Doutorado em Psicologia Social) - Pontifícia Universidade Católica de São Paulo, São Paulo, 2011.

DIAMOND, Larry. O espírito da democracia. Curitiba: Instituto Atuação, 2015.

DIAMOND, Larry; PLATTNER, Marc F.; WALKER, Christopher (ed.).

Authoritarianism Goes Global. Baltimore: John Hopkins University Press, 2016.

DREYER, Jaco S. Public theology and the translation imperative: a Ricoeurian perspective. HTS Teologiese Studies, Durbanville, v. 67, n. 3, p. 1-8, 2011.

FAGGIOLI, Massimo. Por que devemos ler Spadaro sobre o "integralismo católico"? IHU On-Line, 20 jul. 2017. Disponível em: http://www.ihu.unisinos.br/186-noticias/noticias2017/569821-por-que-devemos-ler-spadaro-sobre-o-integralismo-catolico. Acesso 17 jul. 2020.

FRAZÃO, Felipe. Por verbas, TVs católicas oferecem a Bolsonaro apoio ao governo. O Estado de S.Paulo, São Paulo, 6 jun. 2020. Disponível em: https://politica.estadao.com.br/noticias/geral,por-verbas-tvs-catolicas-oferecem-abolsonaro-apoio-ao-governo,70003326526. Acesso em: 10 jun. 2020. 
FREEDOM HOUSE. Democracy in crisis. Freedom in the world 2018. Disponível em: https://freedomhouse.org/report/freedom-world/freedom-world-2018. Acesso em: 3 out. 2019.

FREEDOM HOUSE. Global freedom status. Mapa. 2019. Disponível em: https://freedomhouse.org/explore-the-map?type=fiw\&year=2020. Acesso em: 23 jul. 2020.

GONÇALVES, Marcos. Integrismo católico e fundamentalismo protestante comparados: historicidade, aproximações e distanciamentos. Relegens Threskéia, Curitiba, v. 1, n. 2, p. 79-103, 2012.

GROSFOGUEL, Ramon. Hacia un pluri-versalismo transmoderno decolonial. Tabula Rasa, Bogotá, n. 9, p. 199-215, jul.-dez., 2008.

LACERDA, Marina Basso. Neoconservadorismo de periferia: articulação familista, primitiva e neoliberal na Câmara dos Deputados. 2018. Tese (Doutorado em Ciência Política) - Universidade do Estado do Rio de Janeiro, Rio de Janeiro, 2018.

LORO, Marcos Aurélio. Nota de apoio dos claretianos à CNBB. Província Claretiana do Brasil, 9 jun. 2020. Disponível em: http://claret.org.br/noticias/148230/nota-deapoio-dos-claretianos-a-cnbb. Acesso em: 10 jun. 2020.

MACEDO, Edir; OLIVEIRA, Carlos. Plano de poder: Deus, os cristãos e a política. Rio de Janeiro: Thomas Nelson Brasil, 2008.

MARCOS, Ana. Voto evangélico é chave na vitória do "não" no plebiscito da Colômbia. El País, 13 out. 2016. Disponível em: https://brasil.elpais.com/brasil/2016/10/12/internacional/1476237985_601462.html. Acesso em: 10 out. 2019.

MARTÍNEZ AHRENS, Jan. Comediante Jimmy Morales é eleito presidente da Guatemala. El País, 26 out. 2015. Disponível em:

https://brasil.elpais.com/brasil/2015/10/26/internacional/1445824124_o82191.html. Acesso em: 10 out. 2019.

MATAIS, Andreza; ROSA, Vera; BULLA, Beatriz. PSDB de Aécio Neves pede auditoria na votação. O Estado de S. Paulo, São Paulo, 30 out. 2014. Disponível em: https://politica.estadao.com.br/noticias/geral,psdb-de-aecio-neves-pede-auditoria-navotacao,1585755. Acesso em: 3 out. 2019.

MIGUEL, Luiz Felipe. Democracia e representação: territórios em disputa. São Paulo: Editora Unesp, 2014.

NASCIMENTO, Gilberto. Sem fiéis, sem dízimo, sem palanque: epidemia esvazia templos, e igrejas neopentecostais não conseguem pagar horários alugados em emissoras de TV. 29 abr. 2020. Disponível em: https://piaui.folha.uol.com.br/sem-fieis-sem-dizimosem-palanque/. Acesso em: 10 jun. 2020. 
NERI, Marcelo. A escalada da desigualdade: qual foi o impacto da crise sobre a distribuição de renda e a pobreza? Rio de Janeiro: FGV, 2019. Disponível em:

https://cps.fgv.br/desigualdade. Acesso em: 20 dez. 2019.

NERY, Natuza; GUERREIRO, Gabriela. Com discurso agressivo, Aécio quer deixar presidente 'no chão'. Folha de S. Paulo, São Paulo, 4 dez. 2014. Disponível em: http://www1.folha.uol.com.br/poder/2014/12/1557438-com-discurso-agressivo-aecioquer-deixar-presidente-no-chao.shtml. Acesso em: 3 out. 2019.

OXFAM BRASIL. A distância que nos une: um retrato das desigualdades brasileiras. Relatório. Setembro de 2017. Disponível em: https://oxfam.org.br/. Acesso em: 20 dez. 2019.

OXFAM BRASIL; DATAFOLHA. Nós e as desigualdades: percepções sobre desigualdades no Brasil. Relatório. Abril de 2019. Disponível em: https://oxfam.org.br/. Acesso em: 20 dez. 2019.

PIERUCCI, Antonio Flavio. Fundamentalismo e integrismo: os nomes e a coisa. Revista USP, São Paulo, n. 13, p. 144-156, mar.-mai. 1992.

PLATTNER, Marc F. Is Democracy in decline? Journal of Democracy, Washington, D.C., v. 26, n. 1, p. 5-10, 2015.

PRESIDENTA. In: Michaelis: dicionário brasileiro da língua portuguesa. 2015. Disponível em: https://michaelis.uol.com.br/moderno-portugues/. Acesso em: 24 fev. 2021.

REDAÇÃO. "A Bíblia volta ao palácio", diz recém-empossada presidente da Bolívia. Veja,13 nov. 2019. Disponível em: https://veja.abril.com.br/mundo/a-biblia-volta-aopalacio-diz-recem-empossada-presidente-da-bolivia/. Acesso em: 30 nov. 2019.

RICOEUR, Paul. A memória do sofrimento. In: RICOEUR, Paul. A hermenêutica bíblica. São Paulo: Edições Loyola, 2006. p. 239-243.

RICOEUR, Paul. Sobre a tradução. Belo Horizonte: Editora UFMG, 2011.

ROJAS, Ana Gabriela. 3 questões-chave que explicam a vitória de López Obrador na eleição presidencial do México. BBC, 2 jul. 2018. Disponível em:

https://www.bbc.com/portuguese/internacional-44680265. Acesso em: 10 out. 2019.

SANTOS, Boaventura de Sousa. Se Deus fosse um ativista dos direitos humanos. São Paulo: Cortez, 2014.

SBARDELOTTO, Moisés. A “inutilidade” das mídias católicas. 10 jun. 2020. Disponível em: http://www.ihu.unisinos.br/599843-a-inutilidade-das-midias-catolicas. Acesso em: 10 jun. 2020.

SCHWINDT, Luiz Carlos. Sobre gênero neutro em português brasileiro e os limites do sistema linguístico. Revista da ABRALIN, v. 19, n. 1, p. 1-23, 17 nov. 2020. 
SILVA, Hiram Reis e. Desafiando o rio-mar: descendo o Solimões. Porto Alegre: EDIPUCRS, 2010.

SMYDA, Mieczyslaw. Nota de esclarecimento. Província dos Jesuítas do Brasil, 7 jun. 2020. Disponível em: https://www.jesuitasbrasil.org.br/2020/06/o7/nota-deesclarecimento-da-provincia-dos-jesuitas-do-brasil/. Acesso em: 10 jun. 2020.

SOUZA, Jessé. A construção social da subcidadania: para uma sociologia política da modernidade periférica. Belo Horizonte: Editora UFMG; Rio de Janeiro: Iuperj, 2003.

SPADARO, Antonio; FIGUEROA, Marcelo. Fundamentalismo evangélico e integralismo católico: um "ecumenismo do ódio". IHU On-Line, jul. 2017. Disponível em: http://www.ihu.unisinos.br/569668-fundamentalismo-evangelico-e-integralismocatolico-um-ecumenismo-surpreendente. Acesso em: 20 out. 2019.

TAYLOR, James. Hospitality as translation. In: KEARNEY, Richard; TAYLOR, James. (ed.). Hosting the stranger: between religions. New York; London: Continuum, 2011. p. 11-21.

THE ECONOMIST INTELLIGENCE UNIT. Democracy index 2018: me too? Political participation, protest and democracy. Publicado em 2019. Disponível em:

http://www.eiu.com/. Acesso em: 31 jul. 2020.

THE ECONOMIST INTELLIGENCE UNIT. Democracy index 2019: a year of democratic setbacks and popular protest. Publicado em 2020. Disponível em: http://www.eiu.com/. Acesso em: 31 jul. 2020.

THE ECONOMIST INTELLIGENCE UNIT. Infográfico. Disponível em: https://infographics.economist.com/2019/DemocracyIndex/. Acesso em: 3 out. 2019.

TODOROV, Tzvetan. Os inimigos íntimos da democracia. São Paulo: Companhia das Letras, 2012.

VOLP - Vocabulário Ortográfico da Língua Portuguesa. 5. ed. Rio de Janeiro: Academia Brasileira de Letras, 2009. Disponível em: https://www.academia.org.br/nossalingua/busca-no-vocabulario. Acesso em: 24 fev. 2021.

YOUTUBE. Oração em favor do Brasil com a presença do Presidente Bolsonaro e líderes evangélicos. Canal Silas Malafaia Oficial. Transmitido em 5 jun. 2020. Disponível em: https://www.youtube.com/watch?v=Fhn9-bLRxio\&feature=youtu.be. Acesso em: 5 jun. 2020.

YOUTUBE. Plenário - Sessão Deliberativa - 17/o4/2016 - 14:oo. Canal Câmara dos Deputados. Disponível em: https://www.youtube.com/watch?v=2LC_v4J3waU. Acesso em: 16 jul. 2020.

ZANOTTO, Gizele. Porque nós queríamos formar uma confederação mundial: a expansão do integrismo de Plínio Corrêa de Oliveira para a Argentina (anos 1960). Revista Brasileira de História das Religiões, Maringá, v. 12, n. 36, p. 201-221, jan.-abr. 2020. 
ZEFERINO, Jefferson. Estudos sobre teologia pública no contexto brasileiro: aspectos de um campo de pesquisa em construção. Revista Brasileira de História das Religiões, Maringá, v. 12, n. 36, p. 151-166, 2020.

ZEFERINO, Jefferson. Karl Barth e teologia pública: contribuições ao discurso teológico público na relação entre clássicos teológicos e res publica no horizonte da teologia da cidadania. 2018. Tese (Doutorado em Teologia) - Pontifícia Universidade Católica do Paraná, Curitiba, 2018. 